Article

\title{
Examination of the Novel Sigma-1 Receptor Antagonist, SI 1/28, for Antinociceptive and Anti-allodynic Efficacy against Multiple Types of Nociception with Fewer Liabilities of Use
}

\author{
Lisa L. Wilson ${ }^{1}$, Shainnel O. Eans ${ }^{1}$, Insitar Ramadan-Siraj ${ }^{1}$, Maria N. Modica ${ }^{2} \mathbb{D}$, Giuseppe Romeo ${ }^{2} \mathbb{D}$, \\ Sebastiano Intagliata $2, *$ (D) and Jay P. McLaughlin $1, * \mathbb{D}$
}

check for updates

Citation: Wilson, L.L.; Eans, S.O.; Ramadan-Siraj, I.; Modica, M.N.; Romeo, G.; Intagliata, S.; McLaughlin, J.P. Examination of the Novel Sigma-1 Receptor Antagonist, SI 1/28, for Antinociceptive and Anti-allodynic Efficacy against Multiple Types of Nociception with Fewer Liabilities of Use. Int. J. Mol. Sci. 2022, 23, 615. https://doi.org/10.3390/ ijms23020615

Academic Editor:

Christophe Morisseau

Received: 13 December 2021

Accepted: 29 December 2021

Published: 6 January 2022

Publisher's Note: MDPI stays neutral with regard to jurisdictional claims in published maps and institutional affiliations.

Copyright: (C) 2022 by the authors. Licensee MDPI, Basel, Switzerland. This article is an open access article distributed under the terms and conditions of the Creative Commons Attribution (CC BY) license (https:// creativecommons.org/licenses/by/ $4.0 /)$.
1 Department of Pharmacodynamics, The University of Florida, Gainesville, FL 32610, USA; lisawilson@ufl.edu (L.L.W.); shaieans@cop.ufl.edu (S.O.E.); I.SirajRamadan@hotmail.com (I.R.-S.)

2 Department of Drug and Health Sciences, University of Catania, 95125 Catania, Italy; mmodica@unict.it (M.N.M.); gromeo@unict.it (G.R.)

* Correspondence: s.intagliata@unict.it (S.I.); jmclaughlin@cop.ufl.edu (J.P.M.); Tel.: +39-095-738-4053 (S.I.); +1-352-273-7207 (J.P.M.)

\begin{abstract}
Neuropathic pain is a significant problem with few effective treatments lacking adverse effects. The sigma-1 receptor (S1R) is a potential therapeutic target for neuropathic pain, as antagonists for this receptor effectively ameliorate pain in both preclinical and clinical studies. The current research examines the antinociceptive and anti-allodynic efficacy of SI $1 / 28$, a recently reported benzylpiperazine derivative and analog of the S1R antagonist SI 1/13, that was 423 -fold more selective for S1R over the sigma-2 receptor (S2R). In addition, possible liabilities of respiration, sedation, and drug reinforcement caused by SI $1 / 28$ have been evaluated. Inflammatory and chemical nociception, chronic nerve constriction injury (CCI) induced mechanical allodynia, and adverse effects of sedation in a rotarod assay, conditioned place preference (CPP), and changes in breath rate and locomotor activity were assessed after i.p. administration of SI 1/28. Pretreatment with SI 1/28 produced dose-dependent antinociception in the formalin test, with an $\mathrm{ED}_{50}$ (and 95\% C.I.) value of 13.2 (7.42-28.3) $\mathrm{mg} / \mathrm{kg}$, i.p. Likewise, SI 1/28 produced dose-dependent antinociception against visceral nociception and anti-allodynia against CCI-induced neuropathic pain. SI 1/28 demonstrated no impairment of locomotor activity, conditioned place preference, or respiratory depression. In summary, SI 1/28 proved efficacious in the treatment of acute inflammatory pain and chronic neuropathy without liabilities at therapeutic doses, supporting the development of S1R antagonists as therapeutics for chronic pain.
\end{abstract}

Keywords: sigma; sigma-1 receptor; antagonist; allodynia; analgesia; neuropathic pain; sedation

\section{Introduction}

Chronic neuropathic pain is a common cause for decreased quality of life and disability in the United States [1]. Chronic pain may be caused by disease or lesions within A $\beta$, $A \delta$ and $C$ fibers as well as central neurons found in the somatosensory system [2]. First and second line pharmacological treatments for this type of pain include antiepileptics and antidepressants, respectively [3,4], but these medications possess adverse effects including sedation, dizziness, and impaired locomotion [2], presenting a significant risk of falling and while operating machinery, thus lowering patient compliance. Similarly, third line treatment of neuropathic pain with opioids may produce adverse effects including tolerance, constipation, substance abuse and respiratory depression which can result in death $[5,6]$. Worse, the established treatments for chronic pain have been limited efficacy in approximately 50\% of patients [4]. Overall, there is a clear need to find more effective analgesic therapeutic options with fewer liabilities to treat chronic pain [7]. 
Once thought to be a member of the opioid family [8], cloning of the sigma-1 receptor (S1R) in 1996 [9] established it as a ligand-regulated, intracellular chaperone protein expressed in primary sensory neurons involved in pain transduction [10]. S1R have been localized in the lumbar dorsal root ganglia in neuropathic states such as spared nerve injury and sciatica [10]. S1R in the peripheral and central nervous systems play a pivotal role in the hypersensitivity of pain and the function of nociception [11-14]. A growing number of studies indicate that inactivation or antagonism of S1R produces antinociception in both inflammatory-induced and neuropathic pain models [12,13,15,16]. However, many existing S1R antagonists currently used clinically, such as dextromethorphan, haloperidol, and imipramine, demonstrate poor S1R selectivity and significant off-target activity [12]. Recently, the push for highly selective S1R antagonists as therapeutics for neuropathic pain yielded MR309 (also known as E-52862), an S1R antagonist in phase IIa clinical trials for oxaliplatin-induced peripheral neuropathy [17], and $\left[{ }^{18} \mathrm{~F}\right] \mathrm{FTC}-146$, which completed phase I clinical trials as a highly selective S1R PET imaging agent to visualize nerve damage in neuropathic states [18-21]. Extending this effort, we recently identified SI 1/13, a selective benzylpiperazine-based S1R antagonist with a S2R/S1R selectivity ratio of 886 that demonstrated efficacy against chronic constrictive nerve injury (CCI)-induced neuropathic pain and formalin-induced inflammatory pain without impairing locomotor activity [22]. In addition, SI 1/13 demonstrated significant cytotoxic effects towards DU145 and U87MG cancer cells, further corroborating its function profile as a S1R antagonist [23,24].

The current study sought to characterize an analog of SI 1/13, 1-(4-\{[4-(hydroxymethyl) phenyl]methyl\}piperazin-1-yl)-5-phenylpentan-1-one oxalate (named herein SI 1/28), for its ability to modulate chronic neuropathic and inflammatory pain states in mice. As reported previously (as compound 24; see [22]), radioligand binding studies found SI 1/28 to have high affinity for the S1R $\left(K_{\mathrm{i}} \mathrm{S} 1 \mathrm{R}=6.1 \mathrm{nM}\right)$ over the sigma-2 receptor $\left(K_{\mathrm{i}} \mathrm{S} 2 \mathrm{R}=2,583 \mathrm{nM}\right)$ for a S2R/S1R selectivity ratio of 423 deemed desirable for further examination. As in vitro functional assays to assess S1R activity remain under development [25], we relied on established in vivo approaches, testing with rodent models to determine the functionality of SI 1/28 in assays of inflammatory pain and chronic neuropathic pain [14,15,26]. Based on the structural similarity to the parent compound and reported S1R antagonist SI $1 / 13$ [22], we hypothesized that SI 1/28 would likewise demonstrate anti-inflammatory, anti-allodynic, and anti-hyperalgesic effects in a battery of mouse models of nociception and pain $[15,16,26]$ with reduced liabilities associated with opioids such as drug seeking, respiratory depression, and locomotor impairment or sedation [26-28].

\section{Results}

2.1. SI 1/28 Induces Dose-Dependent Antinociception in Mouse Models of Visceral Chemical and Inflammatory Nociception

Following administration through the intraperitoneal (i.p.) route, SI 1/28 dose dependently increased antinociception in the acetic acid writhing test with an $\mathrm{ED}_{50}$ (and $95 \%$ C.I) value of $27.4(16.0-43.7) \mathrm{mg} / \mathrm{kg}$, i.p. (Figure 1). These effects were significantly less potent $\left(\mathrm{F}_{(2,107)}=21.18, p<0.0001\right.$; nonlinear regression modeling) than the effects of the parent compound SI 1/13 ( $\mathrm{ED}_{50}$ (and 95\% C.I.) value of $2.67(1.34-4.27) \mathrm{mg} / \mathrm{kg}$, i.p; Figure 1), the nonselective opioid positive control, morphine ( $\mathrm{ED}_{50}$ (and $95 \%$ C.I.) value of $0.74(0.40-1.21) \mathrm{mg} / \mathrm{kg}$, i.p; Figure 1) and known kappa opioid receptor (KOR) agonist, $\mathrm{U} 50,488$, with an $\mathrm{ED}_{50}$ (and 95\% C.I.) value of $2.22(0.63-5.08) \mathrm{mg} / \mathrm{kg}$, i.p. (Figure 1).

When evaluated in the formalin assay, SI 1/28 demonstrated a dose-dependent decrease in summed duration of licking with an $\mathrm{ED}_{50}$ (and $95 \%$ C.I.) value of 13.2 (7.42-28.3) $\mathrm{mg} / \mathrm{kg}$, i.p (Figure 2). The effects against formalin induced inflammatory pain were significantly less potent $\left(\mathrm{F}_{(1,98)}=37.8, p<0.0001\right.$; nonlinear regression modeling) than demonstrated by control compound morphine ( $\mathrm{ED}_{50}$ (and 95\% C.I.) value $=1.63$ $(0.85-2.58) \mathrm{mg} / \mathrm{kg}$, i.p; Figure 2), but equivalent to the efficacy of the parent S1R antagonist, SI 1/13 (ED 50 (and 95\% C.I.) value of $12.7(9.89-16.6) \mathrm{mg} / \mathrm{kg}$, i.p. [22]. 


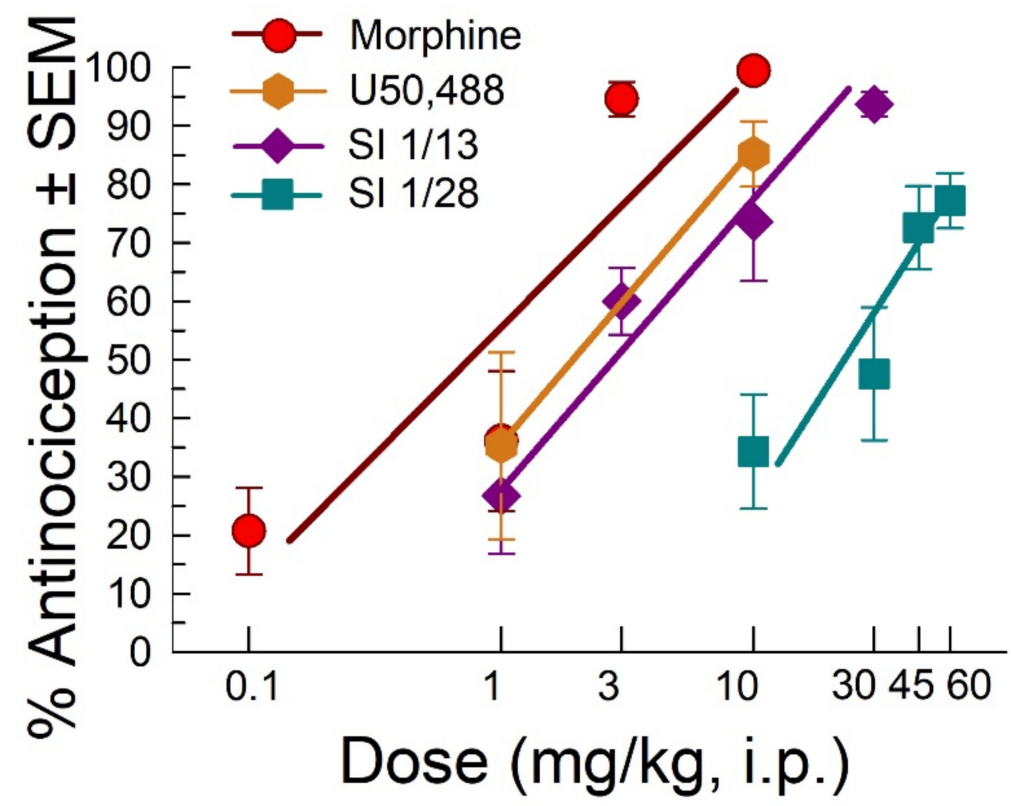

Figure 1. Dose-dependent antinociception of SI 1/28 following i.p. administration in the mouse acetic-acid writhing assay. Opioid agonists morphine, U50,488, and the parent S1R antagonist, SI $1 / 13$ are shown as positive controls. All points represent average response \pm SEM at peak effect, 30 min after administration in 7-10 mice.

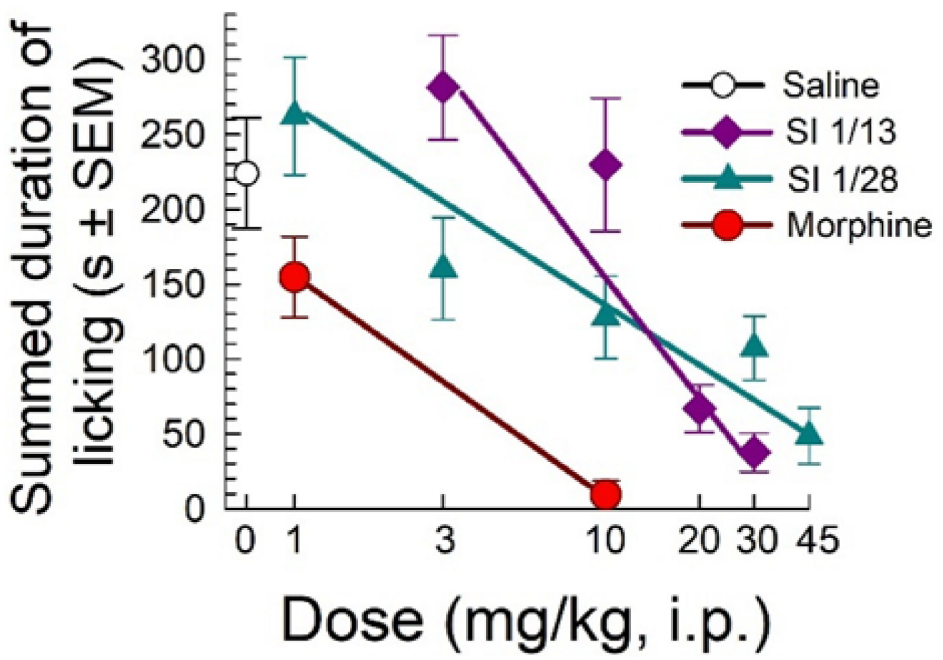

Figure 2. Dose-dependent antinociception of SI 1/28 following i.p. administration in the mouse formalin assay. Control mice were treated with saline $(0.9 \%)$, morphine or the parent S1R antagonist, SI 1/13. All points represent summed time spent licking \pm SEM of 7-13 mice. Note that SI 1/13 data is as previously published in reference [22].

\subsection{Anti-Allodynic Effects of SI $1 / 28$}

One week after chronic constriction nerve injury (CCI), mice displayed characteristic mechanical allodynia (white diamond) that was unchanged by treatment with vehicle, but significantly ameliorated for up to $60 \mathrm{~min}$ after a $1 \mathrm{~h}$ pretreatment with gabapentin $\left(50 \mathrm{mg} / \mathrm{kg}\right.$, i.p.; time $\mathrm{x}$ treatment, $\mathrm{F}_{(3,66)}=7.31, p=0.0003$; two-way RM ANOVA with Tukey's multiple comparisons post hoc test; Figure 3) for up to $60 \mathrm{~min}$. Treatment with SI $1 / 28$ significantly increased paw withdrawal threshold in mice exposed to CCI in a time$\left(\mathrm{F}_{(2.49,119.6)}=4.20, p=0.01\right.$; two-way RM ANOVA with Tukey's multiple comparisons post hoc test) and dose-dependent manner $\left(\mathrm{F}_{(4,48)}=10.2, p<0.0001\right.$; two-way RM ANOVA with Tukey's post hoc test; Figure 3) compared to the saline control. While SI 1/28 did 
not significantly attenuate allodynia after treatment with a $3 \mathrm{mg} / \mathrm{kg}$, i.p. (orange squares, Figure 3), a $10 \mathrm{mg} / \mathrm{kg}$, i.p. dose was approximately 50-60\% effective at reversing mechanical allodynia beginning at $40 \mathrm{~min}$ post-administration, and a $45 \mathrm{mg} / \mathrm{kg}$, i.p. dose significantly reduced allodynia at $60 \mathrm{~min}(p=0.006)$ and $80 \mathrm{~min}(p=0.02)$. Notably, a direct comparison of SI 1/28 and the parent compound SI 1/13 (at doses of $45 \mathrm{mg} / \mathrm{kg}$, i.p.) demonstrated that SI $1 / 28$ was significantly more efficacious in ameliorating mechanical allodynia $\left(\mathrm{F}_{(3,81)}=3.16\right.$, $p=0.03$; two-way RM ANOVA; Figure 3).

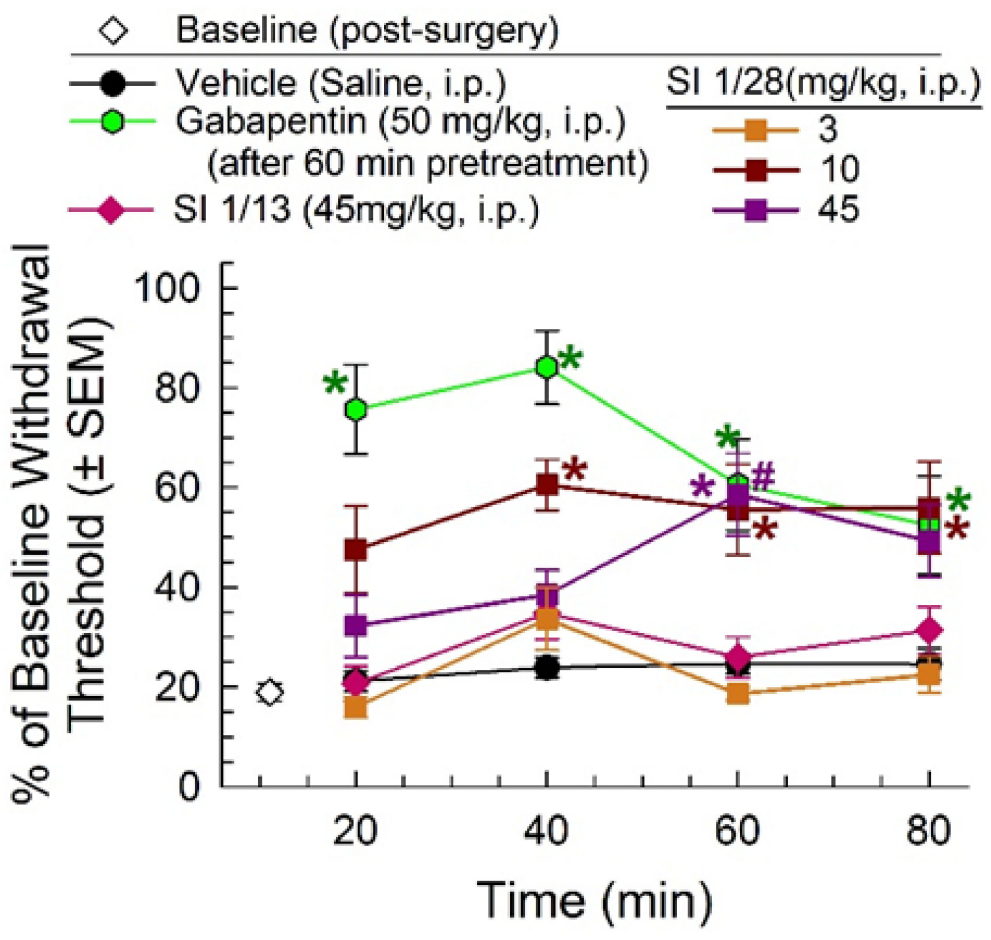

Figure 3. Dose- and time-dependent anti-allodynic activity of SI 1/28 (squares) in the mouse CCI assay of neuropathic pain. Mechanical allodynia produced from sciatic nerve ligation was reduced from 40-80 $\mathrm{min}$ (10 mg/kg, i.p., red squares) and 60-80 $\mathrm{min}$ (45 mg/kg, i.p.; purple squares), similar to the effect of the positive control, gabapentin (green hexagon). SI 1/28 (45 mg/kg, i.p.; purple squares) was significantly increased compared to the parent compound, SI 1/13 (pink diamonds). $n=8-17$ for all groups. ${ }^{*}=$ significantly different from vehicle controls; $\#=$ significantly different from SI 1/13; $p<0.05$; two-way RM ANOVA.

\subsection{Evaluation of SI 1/28 for Potential Clinical Liabilities}

In the conditioned place preference (CPP) assay, morphine $(10 \mathrm{mg} / \mathrm{kg}$, i.p.) produced significant differences between pre- and post-conditioning responses (conditioning $\mathrm{x}$ treatment: $\mathrm{F}_{(1,40)}=15.3, p=0.0003$; two-way RM ANOVA with Sidak's multiple comparisons post hoc test; Figure 4). In contrast, SI 1/28 did not demonstrate significant conditioned place preference $(p=0.07)$.

In evaluation of spontaneous locomotor activity and respiratory effects using the Comprehensive Lab Animal Monitoring System (CLAMS), morphine (30 mg/kg, i.p.) demonstrated significant increases in ambulation from 20-120 min post-treatment (treatment: $\mathrm{F}_{(2,33)}=103.3 ; p<0.0001$ and time: $\mathrm{F}_{(5,165)}=114.7 ; p<0.0001$; two-way RM ANOVA with Dunnett's multiple comparisons post hoc test; Figure 5a). In contrast, SI $1 / 28$ (60 mg/kg, i.p.) produced no significant changes in spontaneous ambulation at any time point $(p>0.05)$. Morphine also produced significant reductions in respiration rate between $0-80$ min post-injection (treatment: $\mathrm{F}_{(2,33)}=9.25 ; p<0.0006$ and time: $\mathrm{F}_{(5,165)}=5.37$; $p<0.0001$; two-way ANOVA with Dunnett's post hoc test; Figure 5b). Again, SI 1/28 had no significant effects on breaths per minute compared to the saline control $(p>0.05)$ for all time points. 


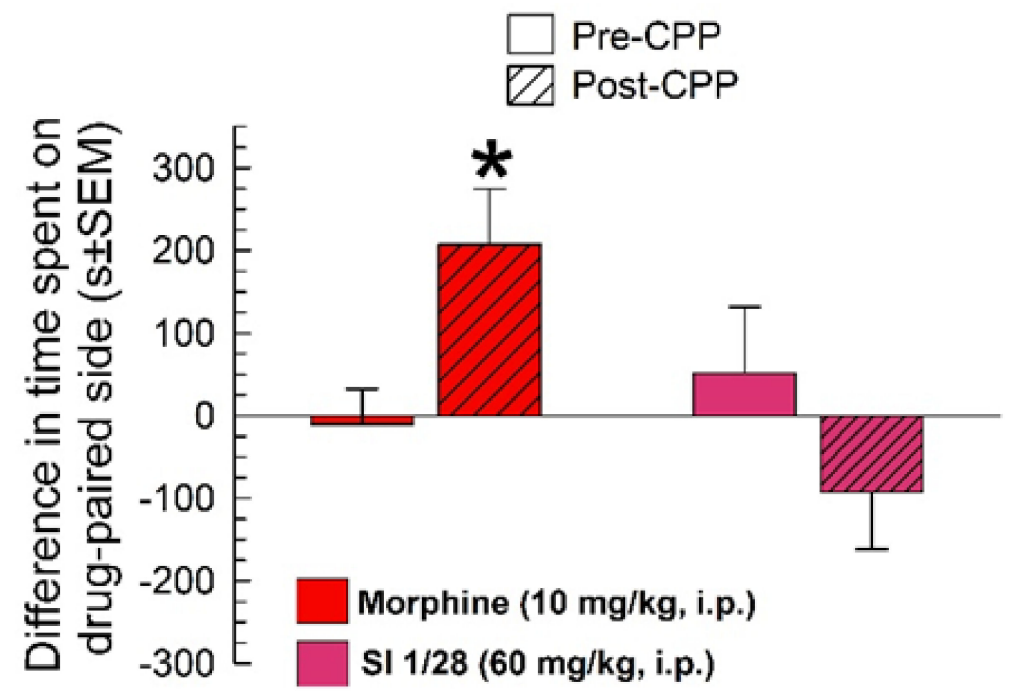

Figure 4. SI $1 / 28$ (60 mg/kg/d, i.p.; $n=20)$ did not demonstrate place conditioning preference or aversion, whereas morphine $(10 \mathrm{mg} / \mathrm{kg}$, i.p.) showed significant conditioned place preference $(n=22)$ in the mouse conditioned place preference assay. ${ }^{*}=$ post-conditioning response (striped bars) significantly different from matching pre-CPP response (matching open bars), $p=0.003$; two-way RM ANOVA w/Sidak's post hoc test.

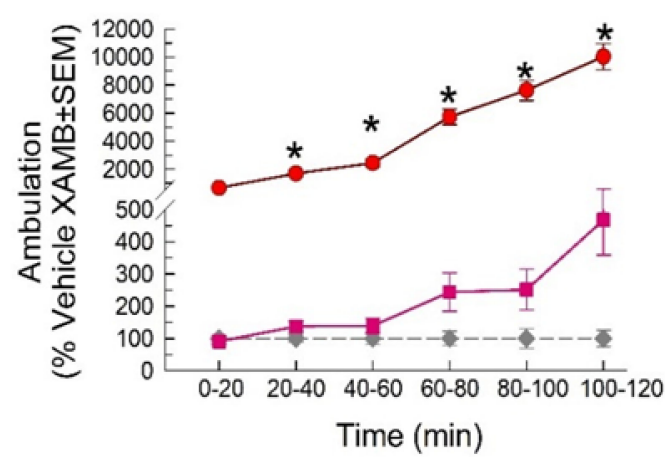

(a)

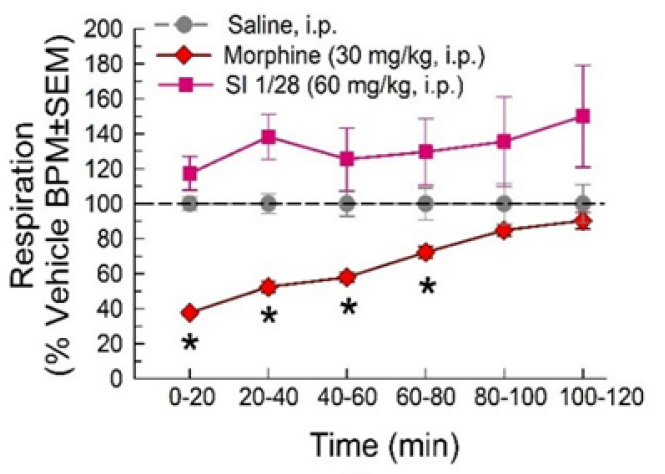

(b)

Figure 5. Dose- and time-dependent (a) spontaneous ambulation and (b) respiratory effects of morphine (30 mg/kg, i.p.; red circles) or SI 1/28 (60 mg/kg, i.p.; pink squares) evaluated in the CLAMS/Oxymax system with C57BL6/J mice. * = significantly greater than vehicle effect (gray dashed line), $p<0.05$; two-way ANOVA w/Dunnett's post hoc test. $n=12$ mice/group. Data presentenced as \% vehicle response \pm SEM; ambulation, XAMB (a) or breaths per minute, BPM (b).

Changes in evoked or sedative-like effects were evaluated using the rotarod apparatus. The KOR agonist, U50,488, impaired locomotion compared to saline (treatment: $\mathrm{F}_{(3,259)}=34.7, p<0.0001$ and time: $\mathrm{F}_{(6,259)}=3.04, p=0.0068$, Two-way RM ANOVA with Dunnett's post hoc test; Figure 6). However, neither the 45 or $60 \mathrm{mg} / \mathrm{kg}$ (i.p.) doses of SI $1 / 28$ impaired evoked locomotion or produced sedative-like effects as compared to the vehicle control $(p>0.05)$. 


\section{SI $1 / 28(\mathrm{mg} / \mathrm{kg}$, i.p.)}
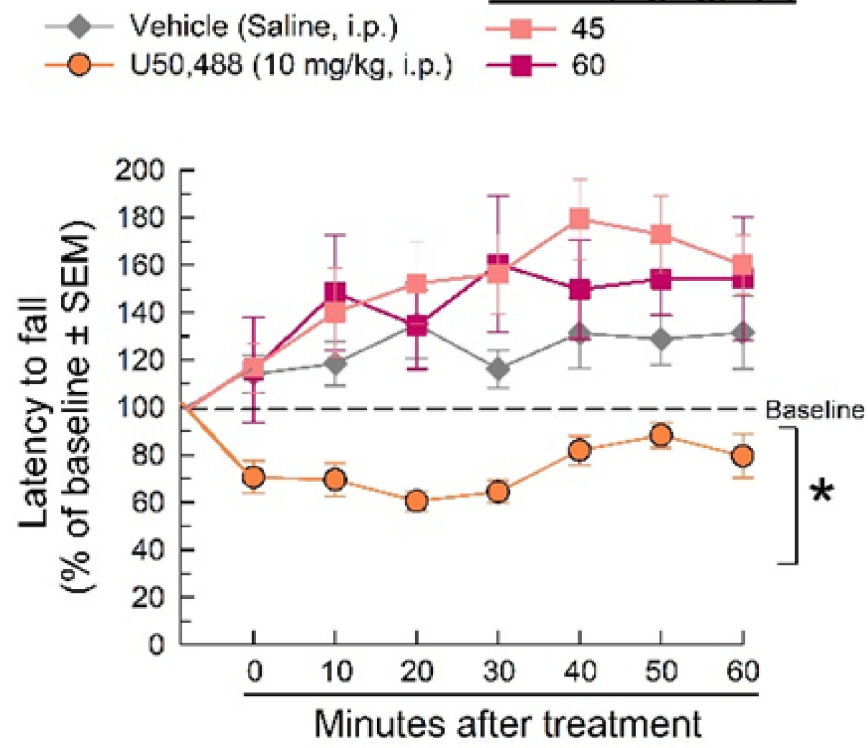

Figure 6. Dose- and time-dependent effects of SI 1/28 (squares) after 45 and $60 \mathrm{mg} / \mathrm{kg}$ i.p. administration in the mouse rotarod assay. U50,488 $(10 \mathrm{mg} / \mathrm{kg}$, i.p; orange circles.) is the positive control. * = significantly different than vehicle ( $0.9 \%$ saline; gray diamonds), $p<0.05$; two-way ANOVA $\mathrm{w} /$ Dunnett's post hoc test; $n=8-12$ mice/treatment.

\section{Discussion}

The persistence of the opioid epidemic continues to drive an enormous need to produce nonopioid therapeutics for pain [29,30]. Preclinical and clinical research with S1R antagonists has suggested their considerable promise for the potential treatment of chronic neuropathic pain $[13,15,16,26,29,31]$.

Consistent with previous studies conducted with S1R antagonists, SI 1/28 attenuated acute non-reflexive inflammatory pain in the formalin and acetic acid writhing assays [26,32]. After an initial, brief acute pain response associated with the administration of formalin in the test (phase I, thought to be caused by immediate stimulation of peripheral C fibers) [33], phase II is characterized as an extended tonic period of nociception [34,35] that is associated with neuronal sensitization in the spinal cord attributed to stimulation of the afferent nociceptors [36]. The blockade of formalin-induced pain in phase II by SI $1 / 28$ administration is consistent with the reported involvement of S1R in sensitization to nociception [14,37]. In contrast, visceral pain associated with acetic acid administration in the writhing test is attributed to direct activation of the nociceptors in the colon [38]. The hyperalgesia produced by intraperitoneal (i.p.) administered acetic acid in wild-type mice was dose dependently reversed by SI $1 / 28$ pretreatment. Together, these current data suggest that the function of SI $1 / 28$ is in line with antinociceptive properties displayed by other S1R antagonists $[15,17,26,39]$.

While moderately effective, SI 1/28 proved more efficacious than SI 1/13 at alleviating neuropathic pain in the CCI assay. A common clinical therapeutic for neuropathic pain, gabapentin (Neurontin), exhibited strong anti-allodynic effects, but it must be noted this was measured after a $1 \mathrm{~h}$ pretreatment to avoid known sedative effects [3]. SI 1/28 failed to produce anti-allodynic activity at a low dose of $3 \mathrm{mg} / \mathrm{kg}$, i.p., which still demonstrated antinociceptive efficacy in the formalin and acetic acid writhing assays. Failure to produce consistent results across the nociceptive assays points to limitations inherent to fully describing the method of action associated with SI 1/28. In the case of G-protein coupled receptors (GPCRs), these type of effects might be interpreted as due to effects of a partial agonist, many of which have been shown to be effective in the treatment of acute and chronic pain [40]. However, S1Rs are currently classified as ligand-operated chaperone receptors and not GPCRs, and are thus thought to mediate analgesia through interactions 
with a host of proteins influencing nociception $[13,14]$. Understandably, this complicates a ready understanding of the pharmacology and precise mechanisms by which S1R ligands produce antinociception and anti-allodynic effects. As new and more selective antagonists such as SI 1/28 become available, and given the therapeutic promise of existing S1R antagonists such as MR309 [13], further evaluation of the pharmacological mechanisms by which S1R antagonists mediate analgesia are warranted.

Due to their status as chaperone receptors, sigma receptors are not bound by established mechanistic pharmacological rules governing receptor function, raising questions as to the precise mechanisms underlying the action of S1R antagonists. Historically, antinociceptive effects of S1R antagonists have been attributed the S1R's ability to interact with other proteins such as NMDA [41] and opioid [8] receptors, and ion channels such as calcium and potassium channels [42]. Interaction with other proteins could account for some of the antagonistic effects in inflammatory assays, while attenuating anti-neuropathic effects. Elucidating the affinity for other receptor and ion channel targets associated with antinociception is beyond the scope of this study but remains a priority for further investigation.

"Gold standards" for analgesia such as morphine and gabapentin produce some therapeutic benefit against chronic pain, but are associated with liabilities such as decreased respiration, locomotor, and in some cases addiction and death [6,43]. SI 1/28 was assessed for adverse effects such as reward (as conditioned place preference), respiratory depression (as breath rate), and locomotor impairment. In line with previous studies, when tested in the Comprehensive Lab Animal Monitoring System, morphine demonstrated expected spontaneous hyperlocomotion and severely decreased respiration [44,45]. In contrast, SI $1 / 28$ produced no adverse respiratory effects or increased locomotor activity. The current results contrast with previous observations with the selective S1R antagonist CM-304, which displayed hyperventilation at low doses and hypoventilation after treatment with high doses [26]. Cirino and co-authors [26] speculated that S1R concentrations in brain regions that control sedation/arousal (i.e., hypothalamus and medulla) [46] may account for these effects; however, the correlation between the S1R and respiration is not fully understood and warrants further investigation. Moreover, CM-304 retained modest affinity for the S2R (with a $K_{\mathrm{i}}$ value of $364 \mathrm{nM}$, [18]) not possessed by SI $1 / 28$ which could contribute to the discrepancy. Regardless, to confirm the lack of locomotor activity, SI 1/28 was further tested for its ability to impair induced locomotor activity in the rotarod assay. In this case, the S1R antagonist exhibited similar effects to CM-304 with no disruption in evoked locomotor activity [26].

Given reports that rodents self-administer S1R agonists such as PRE-084 at higher doses [47], potential rewarding properties of SI 1/28 were assessed at a supratherapeutic dose, $60 \mathrm{mg} / \mathrm{kg}$. While self-administration studies of SI 1/28 were beyond the scope of the current study, potential rewarding effects were evaluated in the CPP assay. Unlike morphine, which displayed typical rewarding effects in CPP [48,49], SI 1/28 did not produce conditioned place preference. These effects were in accordance with literature demonstrating that S1R antagonists produce neither conditioned place preference nor conditioned place aversion [26]. While the exact mechanism of S1R antagonist activity requires further investigation, an interaction with reward circuitry has been inferred from reports where S1R antagonist treatment blocks sensitization to the locomotor effects of methamphetamine [50], cocaine-seeking behavior and neurotoxicity [51]. Although beyond the scope of the current characterization, further investigation is warranted to evaluate if SI $1 / 28$ modulates the reinforcing effects of methamphetamine and cocaine as reported in the presence of other S1R antagonists.

Currently, these data support the development of S1R-selective antagonists as therapeutics for the treatment of chronic pain. Justifying this, S1R is highly expressed in key areas in the central and peripheral nervous systems regulating the transduction, conduction and perception of pain signals, notably in the dorsal root ganglia [12,31]. Precise mechanistic insights into how S1R modulates neuropathic and acute inflammatory nociception have yet to be elucidated. Of interest, S1R antagonists have proven less effective at modifying 
normal sensitivity thresholds to nociception, perhaps consistent with the reduced liabilities observed such as sedation.

\section{Materials and Methods}

\subsection{Subjects}

Male C57BL/6J and CD-1 with ages ranging 8-12 weeks were housed five to a cage were used. C57BL/6J mice were used in the locomotor and respiration [52], rotarod [53], acetic acid writhing [26], and conditioned place preference [54,55] assays. CD-1 mice were used to verify antinociception in the formalin and chronic constriction nerve injury assay of neuropathic pain [56-59].

ARRIVE guidelines were used to execute and report all animal studies [60]. Treatment groups were blinded and randomly assigned animals. Animals were housed on a 12:12-h light/dark cycle (lights off at 7:00 pm) with ad libitum access to food and water except during experimental sessions. All procedures were Institutional Animal Care and Use Committee (University of Florida) preapproved and conducted in according to the 2011 NIH Guide for the Care and Use of Laboratory Animals.

\subsection{Materials, Drug Preparation, and Administration}

SI 1/28 was resynthesized as a free base following our previous reported synthetic procedures $[22,61,62]$, and then converted into oxalate salt for in vivo testing. The synthetic procedure and experimental data of 1-(4-\{[4-(hydroxymethyl)phenyl]methyl\}piperazin1-yl)-5-phenylpentan-1-one oxalate are reported in the Supplementary Materials. All other chemicals and drugs were purchased from Sigma-Aldrich (St. Louis, MO, USA). Sterile saline $(0.9 \%)$ was used to dissolve morphine and known kappa opioid receptor (KOR) agonist U50488. Gabapentin and SI 1/28 were dissolved in 5\% dimethyl sulfoxide (DMSO) $/ 95 \%$ saline. All drugs were administered intraperitoneally (i.p.) in a volume of $0.25 \mathrm{~mL}$ per $25 \mathrm{~g}$ body weight.

\subsection{Behavioral Assays}

\subsubsection{Acetic Acid Stretching Assay}

Chemically induced visceral pain was assessed in C57BL/6J mice using the acetic acid stretching assay as previously described [53,63]. SI 1/28 (10-60 mg/kg), U50,488 ( 1 and $10 \mathrm{mg} / \mathrm{kg}$ ), or morphine $(0.1-10 \mathrm{mg} / \mathrm{kg}$ ) was administered $25 \mathrm{~min}$. prior to i.p. administration of $0.9 \%$ acetic acid $(0.25 \mathrm{~mL}$ per $25 \mathrm{~g}$ body wt.) to each mouse. After $5 \mathrm{~min}$, the number of stretches presented in each mouse was counted for $15 \mathrm{~min}$. Antinociception was calculated by the formula:

$\%$ antinociception $=([\{$ average stretches in the vehicle group $\}-\{$ number of stretches in each test mouse\}]/[average stretches in vehicle group] $) \times 100$.

\subsubsection{Formalin Assay}

Inflammatory antinociception was evaluated with the use of the formalin assay in C57BL/6J mice as previously described [64]. SI 1/28 (1-45 mg/kg), SI 1/13 (3-30 mg/kg), morphine (1 and $10 \mathrm{mg} / \mathrm{kg}$ ), or saline $(0.9 \%)$ were administered as a $10 \mathrm{~min}$. pretreatment prior to an intraplantar (i.pl.) injection of $5 \%$ formalin $(2.5 \mu \mathrm{g}$ in $15 \mu \mathrm{L})$ administered into the right hind paw. Time spent licking the right hind paw was recorded in 5 min intervals for $60 \mathrm{~min}$ following injection. The last $55 \mathrm{~min}$ of assessment was used to determine inflammatory response stimulus. Data were analyzed as area under the curve (AUC), representing summed time mice spent licking the right hind paw.

\subsubsection{Chronic Constriction Injury (CCI)}

CD-1 mice were used in the CCI assay. Mice were anesthetized with isoflurane as previously described $[26,65]$. Mice then underwent surgery where a small skin incision was made along the exterior of the biceps femoris of the right hind paw [65]. The muscle was split using blunt forceps and the right sciatic nerve was exposed. Two opposite facing 
0.1-10 $\mu \mathrm{L}$ pipette tips were placed under the sciatic nerve to allow for the ease of passing of two sutures under the nerve, $1 \mathrm{~mm}$ apart. The ligatures were tied loosely around the nerve and secured with two knots. The skin incision was closed with two $9 \mathrm{~mm}$ skin staples. After a 7-day recovery period, the mice underwent baseline von Frey testing to confirm acquisition of hyperalgesia or mechanical allodynia.

Von Frey testing was performed as previously described [64,66-68]. Baseline mechanical allodynia readings were taken using the application of filaments with increasing pressure $(0.4-6 \mathrm{~g})$ to the plantar of the hind paw of mice prior to drug administration. Lower withdrawal thresholds of allodynia were considered neuropathic. Vehicle control (saline), gabapentin $(50 \mathrm{mg} / \mathrm{kg})$, or SI 1/28 (3-45 mg/ $\mathrm{kg}$ ) were administered (i.p.), and paw-withdrawal thresholds were recorded from in $20 \mathrm{~min}$ increments until $80 \mathrm{~min}$ postinjection in both the contralateral and ipsilateral hind paws. Time points were measured in triplicate with licking, shaking, or paw withdrawal as indication of a response. It should be noted that gabapentin was administered as a $60 \mathrm{~min}$ pretreatment prior to testing in the CCI assay to avoid confounding sedative effects [69].

\subsubsection{Conditioned Place Preference (CPP)}

Automated, three-compartment place preference chambers were used to evaluate CPP in C57BL/6J mice. A 2day counterbalanced conditioning design [70] was employed with initial place preference evaluation being tested $24 \mathrm{~h}$ prior to place conditioning. In initial preference testing, the mice were allowed free access to all compartments of the apparatus for $30 \mathrm{~min}$ and total time spent in each compartment was recorded. For 2 days following initial preference evaluation, the mice were administered vehicle (5\% DMSO and 95\% saline) then confined into an outer compartment of the apparatus for $40 \mathrm{~min}$. Four h after saline administration, the mice were administered (i.p.) either morphine $(10 \mathrm{mg} / \mathrm{kg})$ or SI $1 / 28(60 \mathrm{mg} / \mathrm{kg})$ then confined in the opposite outer compartment for $40 \mathrm{~min}$. Conditioning restrictions were repeated precisely on day 2 of place conditioning. $24 \mathrm{~h}$ after the second day of conditioning, final place preference was evaluated. Mice were allowed to roam freely between all chambers for $30 \mathrm{~min}$. Data are expressed as the difference in time spent in the drug-paired and vehicle-paired compartments. Positive values represent conditioned preference, whereas negative values are considered conditioned aversion for the drug-paired side.

\subsubsection{Respiratory Depression and Spontaneous Locomotor Testing with CLAMS}

Respiration rate and spontaneous locomotor activity were calculated by the computer automated, Comprehensive Lab Animal Monitoring System (CLAMS; Columbus Instruments, Columbus, $\mathrm{OH}, \mathrm{USA}$,) as described previously [52]. Unrestrained mice were allowed to habituate individually in sealed cages connected to the system for $60 \mathrm{~min}$ preceding testing for initial mouse readings. Mice were then administered i.p. SI 1/28 $(60 \mathrm{mg} / \mathrm{kg})$, morphine $(30 \mathrm{mg} / \mathrm{kg})$, or saline $(0.9 \%)$, and placed back into the CLAMS testing units for $120 \mathrm{~min}$. A built-in pressure transducer within the seal cages was used to measure respiration rates (breaths/min). Spontaneous locomotion was measure via infrared photobeams located at the bottom of each cage. Ambulation was counted as the number of photobeam breaks. All data are expressed as percent of vehicle control response.

\subsubsection{Rotarod Assay to Assess Motor Coordination}

Impairment of evoked locomotor activity or potential sedative effects were measured in the rotarod coordination assay as previously described [53]. Seven training trials were performed where the last training trial was used as a baseline of performance. Vehicle, U50,488 (10 mg/kg), or SI 1/28 (60 mg/kg) was administered (i.p.) then assessed in $10 \mathrm{~min}$ in accelerated speed trials ( $180 \mathrm{~s}$ max latency at $0-20 \mathrm{rpm}$ ) for $60 \mathrm{~min}$. Latency to fall was measured in seconds. Data are reported as the average \% difference from each mouse's baseline latency reading. Reduced latencies to fall in the rotarod test suggest impaired motor coordination or sedation. 


\subsubsection{Statistical Analysis}

Data are presented as mean \pm SEM. GraphPad Prism 7.0 software was used for statistical analysis. Data were analyzed using either one-way or two-way ANOVA with the appropriate post hoc test (Dunnett's, Sidak's, or Tukey's) where $p<0.05$ was considered significant. Linear regression was used to determine $\mathrm{ED}_{50}$ values, and $95 \%$ confidence intervals of dose response cures presented in formalin and acetic acid writhing assays. Condition place preference data are represented as the difference between time spent in the drug pair compartment and the vehicle paired compartment between pre- and postconditioning. CLAMS data are reported as a \% of matching vehicle control responses. The rotarod data are expressed as the \% change from baseline performance for each animal's baseline response.

\section{Conclusions}

The S1R antagonist, SI $1 / 28$, proved efficacious in the treatment of acute inflammatory and visceral nociception and chronic neuropathy, while displaying no significant liabilities of reward, sedation or respiratory depression at therapeutic doses.

Supplementary Materials: The following are available online at https:/ /www.mdpi.com/article/10 $.3390 /$ ijms23020615/s1, synthetic procedure for the preparation of 1-(4-\{[4-(hydroxymethyl)phenyl] methyl\}piperazin-1-yl)-5-phenylpentan-1-one oxalate (SI 1/28), ${ }^{1} \mathrm{H}$ NMR and APT spectra of SI 1/28.

Author Contributions: Conceptualization, S.I. and J.P.M.; methodology, L.L.W., S.O.E., M.N.M., G.R., S.I., J.P.M.; validation, S.I. and J.P.M.; M.N.M. and G.R.; synthesized, purified, and characterized SI 1/28; M.N.M. and G.R.; contributed reagents, materials, and analysis tools; formal analysis, L.L.W., S.I. and J.P.M.; investigation, L.L.W., S.O.E., I.R.-S., S.I., J.P.M.; resources, S.I. and J.P.M.; data curation, L.L.W., S.O.E., I.R.-S., S.I., J.P.M.; writing-original draft preparation, L.L.W., S.I., and J.P.M.; writingreview and editing, L.L.W., S.I., and J.P.M.; visualization, S.I. and J.P.M.; supervision, S.I. and J.P.M.; project administration, S.I. and J.P.M.; funding acquisition, S.I. and J.P.M. All authors have read and agreed to the published version of the manuscript.

Funding: Research Program under Award No. W81XWH-17-1-0558 to J.P.M. Opinions, interpretations, conclusions, and recommendations are those of the authors and are not necessarily endorsed by the Department of Defense. S.I. was supported by PON R\&I funds 2014-2020, CUP: E66C18001320007, AIM1872330, activity 1.

Institutional Review Board Statement: This study was carried out in accordance with the recommendations of the 2011 NIH Guide for the Care and Use of Laboratory Animals and ARRIVE guidelines overseen by the Institutional Animal Care and Use Committee at the University of Florida. The protocol (\#202009530) was approved by the Institutional Animal Care and Use Committee at the University of Florida.

Informed Consent Statement: Not applicable.

Data Availability Statement: Datasets generated for this study are available on request to the corresponding authors.

Conflicts of Interest: The authors declare no conflict of interest. The funders had no role in the design of the study; in the collection, analyses, or interpretation of data; in the writing of the manuscript, or in the decision to publish the results.

\section{References}

1. Nicholson, B.; Verma, S. Comorbidities in chronic neuropathic pain. Pain Med. 2004, 5, S9-S27. [CrossRef] [PubMed]

2. Colloca, L.; Ludman, T.; Bouhassira, D.; Baron, R.; Dickenson, A.H.; Yarnitsky, D.; Freeman, R.; Truini, A.; Attal, N.; Finnerup, N.B.; et al. Neuropathic pain. Nat. Rev. Dis. Primers 2017, 3, 17002. [CrossRef] [PubMed]

3. Gilron, I.; Bailey, J.M.; Tu, D.; Holden, R.R.; Jackson, A.C.; Houlden, R.L. Nortriptyline and gabapentin, alone and in combination for neuropathic pain: A double-blind, randomised controlled crossover trial. Lancet 2009, 374, 1252-1261. [CrossRef]

4. Finnerup, N.B.; Attal, N.; Haroutounian, S.; McNicol, E.; Baron, R.; Dworkin, R.H.; Gilron, I.; Haanpää, M.; Hansson, P.; Jensen, T.S.; et al. Pharmacotherapy for neuropathic pain in adults: A systematic review and meta-analysis. Lancet Neurol. 2015, 14, 162-173. [CrossRef] 
5. Volkow, N.; Benveniste, H.; McLellan, A.T. Use and misuse of opioids in chronic pain. Annu. Rev. Med. 2018, 69, 451-465. [CrossRef] [PubMed]

6. Boom, M.; Niesters, M.; Sarton, E.; Aarts, L.; Smith, T.W.; Dahan, A. Non-analgesic effects of opioids: Opioid-induced respiratory depression. Curr. Pharm. Des. 2012, 18, 5994-6004. [CrossRef]

7. Nelson, L.S.; Juurlink, D.N.; Perrone, J. Addressing the opioid epidemic. JAMA 2015, 314, 1453-1454. [CrossRef]

8. Martin, W.R.; Eades, C.G.; Thompson, J.A.; Huppler, R.E.; Gilbert, P.E. The effects of morphine- and nalorphine- like drugs in the nondependent and morphine-dependent chronic spinal dog. J. Pharmacol. Exp. Ther. 1976, 197, 517-532.

9. Hanner, M.; Moebius, F.F.; Flandorfer, A.; Knaus, H.G.; Striessnig, J.; Kempner, E.; Glossmann, H. Purification, molecular cloning, and expression of the mammalian sigma1-binding site. Proc. Natl. Acad. Sci. USA 1996, 93, 8072-8077. [CrossRef]

10. Shin, S.M.; Wang, F.; Qiu, C.; Itson-Zoske, B.; Hogan, Q.H.; Yu, H. Sigma-1 receptor activity in primary sensory neurons is a critical driver of neuropathic pain. Gene Ther. 2020. [CrossRef]

11. Romero, L.; Merlos, M.; Vela, J.M. Antinociception by Sigma-1 Receptor Antagonists: Central and Peripheral Effects. Adv. Pharmacol. 2016, 75, 179-215.

12. Merlos, M.; Romero, L.; Zamanillo, D.; Plata-Salamán, C.; Vela, J.M. Sigma-1 Receptor and Pain. Handb. Exp. Pharmacol. 2017, 244, 131-161. [PubMed]

13. Castany, S.; Gris, G.; Vela, J.M.; Verdú, E.; Boadas-Vaello, P. Critical role of sigma-1 receptors in central neuropathic pain-related behaviours after mild spinal cord injury in mice. Sci. Rep. 2018, 8, 3873. [CrossRef]

14. Zamanillo, D.; Romero, L.; Merlos, M.; Vela, J.M. Sigma 1 receptor: A new therapeutic target for pain. Eur. J. Pharmacol. 2013, 716, 78-93. [CrossRef]

15. Gris, G.; Merlos, M.; Vela, J.M.; Zamanillo, D.; Portillo-Salido, E. S1RA, a selective sigma-1 receptor antagonist, inhibits inflammatory pain in the carrageenan and complete Freund's adjuvant models in mice. Behav. Pharmacol. 2014, 25, 226-235. [CrossRef] [PubMed]

16. Bravo-Caparrós, I.; Perazzoli, G.; Yeste, S.; Cikes, D.; Baeyens, J.M.; Cobos, E.J.; Nieto, F.R. Sigma-1 receptor inhibition reduces neuropathic pain induced by partial sciatic nerve transection in mice by opioid-dependent and -independent mechanisms. Front. Pharmacol. 2019, 10, 613. [CrossRef]

17. Bruna, J.; Videla, S.; Argyriou, A.A.; Velasco, R.; Villoria, J.; Santos, C.; Nadal, C.; Cavaletti, G.; Alberti, P.; Briani, C.; et al. Efficacy of a novel sigma-1 receptor antagonist for oxaliplatin-induced neuropathy: A randomized, double-blind, placebo-controlled phase IIa clinical trial. Neurotherapeutics 2018, 15, 178-189. [CrossRef]

18. James, M.L.; Shen, B.; Zavaleta, C.L.; Nielsen, C.H.; Mesangeau, C.; Vuppala, P.K.; Chan, C.; Avery, B.A.; Fishback, J.A.; Matsumoto, R.R.; et al. New positron emission tomography (PET) radioligand for imaging $\sigma-1$ receptors in living subjects. J. Med. Chem. 2012, 55, 8272-8282. [CrossRef]

19. James, M.L.; Shen, B.; Nielsen, C.H.; Behera, D.; Buckmaster, C.L.; Mesangeau, C.; Zavaleta, C.; Vuppala, P.K.; Jamalapuram, S.; Avery, B.A.; et al. Evaluation of $\sigma-1$ receptor radioligand ${ }^{18}$ F-FTC-146 in rats and squirrel monkeys using PET. J. Nucl. Med. 2014, 55, 147-153. [CrossRef] [PubMed]

20. Shen, B.; James, M.L.; Andrews, L.; Lau, C.; Chen, S.; Palner, M.; Miao, Z.; Arksey, N.C.; Shuhendler, A.J.; Scatliffe, S.; et al. Further validation to support clinical translation of $\left[{ }^{18} \mathrm{~F}\right] \mathrm{FTC}-146$ for imaging sigma-1 receptors. EJNMMI Res. 2015, 5, 49. [CrossRef] [PubMed]

21. Shen, B.; Park, J.H.; Hjørnevik, T.; Cipriano, P.W.; Yoon, D.; Gulaka, P.K.; Holly, D.; Behera, D.; Avery, B.A.; Gambhir, S.S.; et al. Radiosynthesis and First-In-Human PET/MRI Evaluation with Clinical-Grade [ ${ }^{18}$ F]FTC-146. Mol. Imaging Biol. 2017, 19, 779-786. [CrossRef]

22. Romeo, G.; Bonanno, F.; Wilson, L.L.; Arena, E.; Modica, M.N.; Pittalà, V.; Salerno, L.; Prezzavento, O.; McLaughlin, J.P.; Intagliata, $\mathrm{S}$. Development of new benzylpiperazine derivatives as $\sigma_{1}$ receptor ligands with in vivo antinociceptive and anti-allodynic effects. ACS Chem. Neurosci. 2021, 12, 2003-2012. [CrossRef]

23. Romeo, G.; Ciaffaglione, V.; Amata, E.; Dichiara, M.; Calabrese, L.; Vanella, L.; Sorrenti, V.; Grosso, S.; D’Amico, A.G.; D’Agata, V.; et al. Combination of heme oxygenase-1 inhibition and sigma receptor modulation for anticancer activity. Molecules 2021, 26, 3860. [CrossRef]

24. Fallica, A.N.; Pittalà, V.; Modica, M.N.; Salerno, L.; Romeo, G.; Marrazzo, A.; Helal, M.A.; Intagliata, S. Recent advances in the development of sigma receptor ligands as cytotoxic agents: A medicinal chemistry perspective. J. Med. Chem. 2021, 64, 7926-7962. [CrossRef]

25. Schepmann, D.; Neue, C.; Westphälinger, S.; Müller, C.; Bracher, F.; Lange, C.; Bednarski, P.; Almansa, C.; Friedland, K.; Räbiger V.; et al. Pharmacological characterization of high-affinity $\sigma_{1}$ receptor ligands with spirocyclic thienopyran and thienofuran scaffold. J. Pharm. Pharmacol. 2020, 72, 236-248. [CrossRef]

26. Cirino, T.J.; Eans, S.O.; Medina, J.M.; Wilson, L.L.; Mottinelli, M.; Intagliata, S.; McCurdy, C.R.; McLaughlin, J.P. Characterization of sigma 1 receptor antagonist CM-304 and its analog, AZ-66: Novel therapeutics against allodynia and induced pain. Front. Pharmacol. 2019, 10, 678. [CrossRef] [PubMed]

27. Romieu, P.; Meunier, J.; Garcia, D.; Zozime, N.; Martin-Fardon, R.; Bowen, W.D.; Maurice, T. The sigma1 (sigma1) receptor activation is a key step for the reactivation of cocaine conditioned place preference by drug priming. Psychopharmacology 2004, 175, 154-162. [CrossRef] 
28. Chen, S.L.; Hsu, K.Y.; Huang, E.Y.; Lu, R.B.; Tao, P.L. Low doses of dextromethorphan attenuate morphine-induced rewarding via the sigma-1 receptor at ventral tegmental area in rats. Drug Alcohol Depend. 2011, 117, 164-169. [CrossRef]

29. Abadias, M.; Escriche, M.; Vaqué, A.; Sust, M.; Encina, G. Safety, tolerability and pharmacokinetics of single and multiple doses of a novel sigma-1 receptor antagonist in three randomized phase I studies. Br. J. Clin. Pharmacol. 2013, 75, 103-117. [CrossRef]

30. Fraser, M.R.; Levine, M. A Comprehensive Approach to Addressing the Opioid Crisis. In A Public Health Guide to Ending the Opioid Epidemic; Oxford University Press: Oxford, UK, 2019.

31. Merlos, M.; Burgueño, J.; Portillo-Salido, E.; Plata-Salamán, C.R.; Vela, J.M. Pharmacological modulation of the sigma 1 receptor and the treatment of pain. Adv. Exp. Med. Biol. 2017, 964, 85-107.

32. Vidal-Torres, A.; Fernández-Pastor, B.; Carceller, A.; Vela, J.M.; Merlos, M.; Zamanillo, D. Effects of the selective sigma-1 receptor antagonist S1RA on formalin-induced pain behavior and neurotransmitter release in the spinal cord in rats. J. Neurochem. 2014, 129, 484-494. [CrossRef]

33. McCall, W.D.; Tanner, K.D.; Levine, J.D. Formalin induces biphasic activity in C-fibers in the rat. Neurosci. Lett. 1996, $208,45-48$. [CrossRef]

34. Wheeler-Aceto, H.; Cowan, A. Standardization of the rat paw formalin test for the evaluation of analgesics. Psychopharmacology 1991, 104, 35-44. [CrossRef]

35. Abbott, F.V.; Franklin, K.B.J.; Westbrook, F.R. The formalin test: Scoring properties of the first and second phases of the pain response in rats. Pain 1995, 60, 91-102. [CrossRef]

36. Baba, H.; Doubell, T.P.; Woolf, C.J. Peripheral inflammation facilitates Abeta fiber-mediated synaptic input to the substantia gelatinosa of the adult rat spinal cord. J. Neurosci. 1999, 19, 859-867. [CrossRef]

37. Drews, E.; Zimmer, A. Central sensitization needs sigma receptors. Pain 2009, 145, 269-270. [CrossRef]

38. Cervero, F.; Laird, J.M.A. Spinal Mechanisms of Visceral Pain and Hyperalgesia. In Synaptic Plasticity in Pain; Malcangio, M., Ed.; Springer: New York, NY, USA, 2009; pp. 289-306.

39. Puente, B.; Nadal, X.; Portillo-Salido, E.; Sánchez-Arroyos, R.; Ovalle, S.; Palacios, G.; Muro, A.; Romero, L.; Entrena, J.M.; Baeyens, J.M.; et al. Sigma-1 receptors regulate activity-induced spinal sensitization and neuropathic pain after peripheral nerve injury. Pain 2009, 145, 294-303. [CrossRef]

40. Budd, K. The use of partial antagonist analgesics in the treatment of acute and chronic pain. Can. Anaesth. Soc. J. 1985, 32, 399-401. [CrossRef]

41. Wong, E.H.; Knight, A.R.; Woodruff, G.N. $\left[{ }^{3} \mathrm{H}\right] \mathrm{MK}-801$ labels a site on the N-methyl-D-aspartate receptor channel complex in rat brain membranes. J. Neurochem. 1988, 50, 274-281. [CrossRef]

42. Palmer, C.P.; Aydar, E.; Jackson, M.B. $\sigma$ Receptor Modulation of Ion Channels. In Sigma Receptors: Chemistry, Cell Biology and Clinical Implications; Su, T.-P., Matsumoto, R.R., Bowen, W.D., Eds.; Springer: Boston, MA, USA, 2007; pp. 127-149.

43. Evoy, K.E.; Morrison, M.D.; Saklad, S.R. Abuse and misuse of pregabalin and gabapentin. Drugs 2017, 77, 403-426. [CrossRef]

44. Manzanedo, C.; Aguilar, M.A.; Miñarro, J. The effects of dopamine $\mathrm{D}_{2}$ and $\mathrm{D}_{3}$ antagonists on spontaneous motor activity and morphine-induced hyperactivity in male mice. Psychopharmacology 1999, 143, 82-88. [CrossRef] [PubMed]

45. Imam, M.Z.; Kuo, A.; Smith, M.T. Countering opioid-induced respiratory depression by non-opioids that are respiratory stimulants. F1000Research 2020, 9, F1000. [CrossRef]

46. Lein, E.S.; Hawrylycz, M.J.; Ao, N.; Ayres, M.; Bensinger, A.; Bernard, A.; Boe, A.F.; Boguski, M.S.; Brockway, K.S.; Byrnes, E.J.; et al. Genome-wide atlas of gene expression in the adult mouse brain. Nature 2007, 445, 168-176. [CrossRef]

47. Katz, J.L.; Hiranita, T.; Kopajtic, T.A.; Rice, K.C.; Mesangeau, C.; Narayanan, S.; Abdelazeem, A.H.; McCurdy, C.R. Blockade of cocaine or $\sigma$ receptor agonist self administration by subtype-selective $\sigma$ receptor antagonists. J. Pharmacol. Exp. Ther. 2016, 358, 109-124. [CrossRef]

48. McKendrick, G.; Graziane, N.M. Drug-induced conditioned place preference and its practical use in substance use disorder research. Front. Behav. Neurosci. 2020, 14, 582147. [CrossRef]

49. Vezina, P.; Stewart, J. Morphine conditioned place preference and locomotion: The effect of confinement during training. Psychopharmacology 1987, 93, 257-260. [CrossRef]

50. Tapia, M.A.; Lever, J.R.; Lever, S.Z.; Will, M.J.; Park, E.S.; Miller, D.K. Sigma-1 receptor ligand PD144418 and sigma-2 receptor ligand YUN-252 attenuate the stimulant effects of methamphetamine in mice. Psychopharmacology 2019, 236, 3147-3158. [CrossRef]

51. Maurice, T.; Martin-Fardon, R.; Romieu, P.; Matsumoto, R.R. Sigma ${ }_{1}\left(\sigma_{1}\right)$ receptor antagonists represent a new strategy against cocaine addiction and toxicity. Neurosci. Biobehav. Rev. 2002, 26, 499-527. [CrossRef]

52. Reilley, K.J.; Giulianotti, M.; Dooley, C.T.; Nefzi, A.; McLaughlin, J.P.; Houghten, R.A. Identification of two novel, potent, low-liability antinociceptive compounds from the direct in vivo screening of a large mixture-based combinatorial library. AAPS J. 2010, 12, 318-329. [CrossRef]

53. Eans, S.O.; Ganno, M.L.; Mizrachi, E.; Houghten, R.A.; Dooley, C.T.; McLaughlin, J.P.; Nefzi, A. Parallel synthesis of hexahydrodiimidazodiazepines heterocyclic peptidomimetics and their in vitro and in vivo activities at $\mu$ (MOR), $\delta$ (DOR), and $\kappa($ KOR) opioid receptors. J. Med. Chem. 2015, 58, 4905-4917. [CrossRef]

54. Brabant, C.; Quertemont, E.; Tirelli, E. Influence of the dose and the number of drug-context pairings on the magnitude and the long-lasting retention of cocaine-induced conditioned place preference in C57BL/6J mice. Psychopharmacology 2005, 180, 33-40. [CrossRef] 
55. Orsini, C.; Bonito-Oliva, A.; Conversi, D.; Cabib, S. Susceptibility to conditioned place preference induced by addictive drugs in mice of the C57BL/6 and DBA/2 inbred strains. Psychopharmacology 2005, 181, 327-336. [CrossRef]

56. LaCroix-Fralish, M.L.; Rutkowski, M.D.; Weinstein, J.N.; Mogil, J.S.; Deleo, J.A. The magnitude of mechanical allodynia in a rodent model of lumbar radiculopathy is dependent on strain and sex. Spine 2005, 30, 1821-1827. [CrossRef] [PubMed]

57. Mogil, J.S.; Smith, S.B.; O'Reilly, M.K.; Plourde, G. Influence of nociception and stress-induced antinociception on genetic variation in isoflurane anesthetic potency among mouse strains. Anesthesiology 2005, 103, 751-758. [CrossRef] [PubMed]

58. Feehan, A.K.; Morgenweck, J.; Zhang, X.; Amgott-Kwan, A.T.; Zadina, J.E. Novel endomorphin analogs are more potent and longer-lasting analgesics in neuropathic, inflammatory, postoperative, and visceral pain relative to morphine. J. Pain 2017, 18, 1526-1541. [CrossRef] [PubMed]

59. Intagliata, S.; Sharma, A.; King, T.I.; Mesangeau, C.; Seminerio, M.; Chin, F.T.; Wilson, L.L.; Matsumoto, R.R.; McLaughlin, J.P.; Avery, B.A.; et al. Discovery of a highly selective sigma-2 receptor ligand, 1-(4-(6,7-dimethoxy-3,4-dihydroisoquinolin-2(1H)yl)butyl)-3-methyl-1H-benzo[d]imidazol-2(3H)-one (CM398), with drug-like properties and antinociceptive effects in vivo. AAPS J. 2020, 22, 94. [CrossRef]

60. Kilkenny, C.; Browne, W.J.; Cuthi, I.; Emerson, M.; Altman, D.G. Improving bioscience research reporting: The ARRIVE guidelines for reporting animal research. Vet. Clin. Pathol. 2012, 41, 27-31. [CrossRef]

61. Intagliata, S.; Modica, M.N.; Pittalà, V.; Salerno, L.; Siracusa, M.A.; Cagnotto, A.; Salmona, M.; Kurczab, R.; Romeo, G. New N-and O-arylpiperazinylalkyl pyrimidines and 2-methylquinazolines derivatives as 5- $\mathrm{HT}_{7}$ and $5-\mathrm{HT}_{1 \mathrm{~A}}$ receptor ligands: Synthesis, structure-activity relationships, and molecular modeling studies. Bioorganic Med. Chem. 2017, 25, 1250-1259. [CrossRef]

62. Intagliata, S.; Modica, M.N.; Pittalà, V.; Salerno, L.; Siracusa, M.A.; Cagnotto, A.; Salmona, M.; Romeo, G. Design and synthesis of new homo and hetero bis-piperazinyl-1-propanone derivatives as 5- $\mathrm{HT}_{7} \mathrm{R}$ selective ligands over $5-\mathrm{HT}_{1 \mathrm{~A}} \mathrm{R}$. Bioorganic Med. Chem. Lett. 2016, 26, 4052-4056. [CrossRef]

63. Bidlack, J.M.; Cohen, D.J.; McLaughlin, J.P.; Lou, R.; Ye, Y.; Wentland, M.P. 8-Carboxamidocyclazocine: A long-acting, novel benzomorphan. J. Pharmacol. Exp. Ther. 2002, 302, 374-380. [CrossRef] [PubMed]

64. Cheng, H.Y.; Pitcher, G.M.; Laviolette, S.R.; Whishaw, I.Q.; Tong, K.I.; Kockeritz, L.K.; Wada, T.; Joza, N.A.; Crackower, M.; Goncalves, J.; et al. DREAM is a critical transcriptional repressor for pain modulation. Cell 2002, 108, 31-43. [CrossRef]

65. Hoot, M.R.; Sim-Selley, L.J.; Poklis, J.L.; Abdullah, R.A.; Scoggins, K.L.; Selley, D.E.; Dewey, W.L. Chronic constriction injury reduces cannabinoid receptor 1 activity in the rostral anterior cingulate cortex of mice. Brain Res. 2010, 1339, 18-25. [CrossRef] [PubMed]

66. Bennett, G.J.; Xie, Y.K. A peripheral mononeuropathy in rat that produces disorders of pain sensation like those seen in man. Pain 1988, 33, 87-107. [CrossRef]

67. Pitcher, G.M.; Ritchie, J.; Henry, J.L. Nerve constriction in the rat: Model of neuropathic, surgical and central pain. Pain 1999, 83, 37-46. [CrossRef]

68. Xu, M.; Petraschka, M.; McLaughlin, J.P.; Westenbroek, R.E.; Caron, M.G.; Lefkowitz, R.J.; Czyzyk, T.A.; Pintar, J.E.; Terman, G.W.; Chavkin, C. Neuropathic pain activates the endogenous kappa opioid system in mouse spinal cord and induces opioid receptor tolerance. J. Neurosci. 2004, 24, 4576-4584. [CrossRef]

69. Gilron, I. Gabapentin and pregabalin for chronic neuropathic and early postsurgical pain: Current evidence and future directions. Curr. Opin. Anaesthesiol. 2007, 20, 456-472. [CrossRef]

70. Eans, S.O.; Ganno, M.L.; Reilley, K.J.; Patkar, K.A.; Senadheera, S.N.; Aldrich, J.V.; McLaughlin, J.P. The macrocyclic tetrapeptide [D-Trp]CJ-15,208 produces short-acting k opioid receptor antagonism in the CNS after oral administration. Br. J. Pharmacol. 2013, 169, 426-436. [CrossRef] [PubMed] 